\title{
DESIGN, OPTIMIZATION, AND EVALUATION OF IBUPROFEN FAST-DISSOLVING TABLETS EMPLOYING STARCH VALERATE - A NOVEL SUPER DISINTEGRANT
}

\author{
ANTHOSH KUMAR RADA*, RAMYA M, SHAMBHAVI KANDUKURI \\ GITAM Institute of Pharmacy, GITAM (Deemed to be University), Rushikonda, Visakhapatnam, Andhra Pradesh, India. \\ Email: drsantoshrada@gmail.com
}

Received: 01 March 2021, Revised and Accepted: 15 April 2021

\section{ABSTRACT}

Objective: The main aim is to design, optimize, and evaluate ibuprofen fast-dissolving tablets by employing starch valerate-A novel super disintegrant.

Methods: The fast-dissolving tablet of ibuprofen was prepared by employing starch valerate as super disintegrant in different proportions in each case by direct compression method using 23 factorial design, sodium starch glycolate, and crospovidone used as super disintegrants. In the $2^{3}$ factorial design, these super disintegrants were applied to investigate the interaction effects of three variables, that is, (a) starch valerate, (b) sodium starch glycolate, and (c) crospovidone. The drug content, hardness, friability, disintegration time, and other dissolution characteristics were determined.

Results: The starch valerate prepared was found to be fine, free-flowing, slightly crystalline powder. Starch xanthate exhibited good swelling in water with $125.2 \%$. All the fast-dissolving tablets formulated employing starch valerate were of good quality with regard to drug content (100 $\pm 5 \%$ ), hardness $(3.6-3.8 \mathrm{~kg} / \mathrm{sq} . \mathrm{cm})$, and friability $(0.11-0.12 \%)$. The disintegration time of all the formulated tablets was found to be in the range of $12 \pm 0.02$ to $30 \pm 0.02 \mathrm{~s}$. The optimized formulation FL8 has the least disintegration time, that is, $12 \pm 0.02 \mathrm{~s}$. The in vitro wetting time of the formulated tablets was found to be in the range of $21 \pm 0.09$ to $44 \pm 0.10$ s. The in-vitro wetting time was less (i.e., 90 s) in optimized formulation FL8. The water absorption ratio of the formulated tablets was found to be in the range of $30 \pm 0.12$ to $100 \pm 0.09 \%$.

Conclusion: Starch valerate was found to be a super disintegrant which enhanced the dissolution efficiency when combined with sodium starch glycolate, crospovidone, with the ibuprofen.

Keywords: Fast dissolving, Super disintegrant, Starch valerate, Optimization.

(C) 2021 The Authors. Published by Innovare Academic Sciences Pvt Ltd. This is an open access article under the CC BY license (http://creativecommons.org/ licenses/by/4.0/) DOI: http://dx.doi.org/10.22159/ajpcr.2021v14i5.41264. Journal homepage: https://innovareacademics.in/journals/index.php/ajpcr

\section{INTRODUCTION}

Tablets play a major role in the development of various dosage forms in the drug delivery system because these can be manufactured easily, adequate dosing can be done, stability, and easy to handle. In general, tablets are of many types such as compressed, multi-compressed, enteric-coated, filmcoated, immediate-release (effervescent, sublingual), fast disintegrating, and extended-release tablets. Most of the pharmaceutical dosage forms for oral administration are formulated for direct ingestion, for chewing, for prior dispersion, and/or dissolution in water. Elder people have difficulty in swallowing when prescribed for tablet and capsule forms. The problem of swallowing is also evident in pediatrics, psychiatric, as well as traveling patients who may not have ready access to water. The rapidly disintegrating tablet in the mouth or orodispersible tablets overcome all the above problems and thus offer an alternate form of oral medication, which provide patients with a more convenient means of taking their medication $[1,2]$. Fastdissolving tablets are the dosage forms that disintegrate fastly to release the drug and then dissolve in the saliva, further the drug gets absorbed from the pharynx to different sections of gastrointestinal tract. Hence, these fast-dissolving dosage forms show greater bioavailability than that of conventional dosage forms and it has become a substitute dosage form to geriatrics, pediatrics, and also to those who are bedridden, mentally unwell, fear of swallowing, and these FDTs provide greater patient compliance as there is no requirement of water and shows faster therapeutic action.

When placed on tongue, fast-dissolving tablet allows the fastest bioavailability by disintegrating quickly within few seconds; so, this fast disintegration is due to the presence of super disintegrants which aids for quick disintegration of the tablet, promoting the bioavailability in less time with less concentration [3]. The main reason of this work is to formulate and characterize fast-dissolving tablets of ibuprofen using optimization techniques for rapid dissolution of drug and absorption.

\section{METHODS}

Mannitol, sodium hydroxide, and carbon disulfide were purchased from Finar Chemicals Ltd., Ahmedabad [4]. Ibuprofen, crospovidone, potato starch, sodium starch glycolate, and croscarmellose sodium was obtained from Yarrow chemicals, Mumbai [5]. Starch valerate prepared in the laboratory. Microcrystalline cellulose was brought from Qualigens Fine Chemicals, Mumbai. Talc and magnesium stearate was obtained from Molychem, Mumbai.

\section{PREPARATION OF STARCH VALERATE (A NOVEL SUPER DISINTEGRANT)}

Potato starch was slurried using the distilled water in a beaker and to this valeric acid is added, stirred continuously such that the potato slurry should get mixed properly. Then, $\mathrm{pH}$ should be checked and adjusted to 3.5 by adding $10 \mathrm{M}$ sodium hydroxide solution and conditioned for $16 \mathrm{~h}$ at $60^{\circ} \mathrm{C}$. Hence, after conditioning, the unreacted valeric acid is drained and washed with distilled water and allowed to dry in the oven at $60^{\circ} \mathrm{C}$ for around $2 \mathrm{~h}$. The dried solid mass was then sieved with sieve no. \#120. Then, the obtained fine powder is starch valerate [4].

\section{CHARACTERIZATION OF STARCH VALERATE (NOVEL SUPER DISINTEGRANT)}

The prepared starch valerate was evaluated for the following [4]:

\section{PREPARATION OF IBUPROFEN FAST-DISSOLVING TABLETS}

Ibuprofen, a non-steroidal anti-inflammatory drug, has extensive use in adults and children in order to overcome pain, fever, and inflammation. The use of ODTs could help to reduce the gastrointestinal side effects 
S solubility: Starch valerate solubility has been tested in water and aqueous buffer solutions at various $\mathrm{pH}$ values of $1,2,3,4,5,6$, and 7. Chemical solvents such as alcohol, dichloromethane, chloroform, acetone, and petroleum ether were also checked [4].

pH: Starch valerate, using ELICO $\mathrm{pH}$ analyzer, was made into 1 percent $\mathrm{w} / \mathrm{v}$ of dispersion or slurry and measured for $\mathrm{pH}[4]$.

Viscosity: Starch valerate was transformed into $1 \% \mathrm{w} / \mathrm{v}$ of dispersion or slurry and calculated its viscosity using the Ostwald's viscometer.

Swelling Index: Two $10 \mathrm{ml}$ graduated tubes were taken, starch valerate was applied before $1 \mathrm{ml}$ of labeling was added to them Distilled water and liquid paraffin in one test tube were poured into the other tube and mixed well by shaking. The dispersion obtained was permitted to stand for $12 \mathrm{~h}$ and readings were noted. Sediment volumes in the tubes were documented. The material's swelling index was determined as follows [4].

$$
\text { S.I }(\%)=\frac{V_{w}-V_{L}}{V_{L}} \times 100
$$

$\mathrm{V}_{\mathrm{w}}=$ Volume of sediment in wate

$\mathrm{V}_{\mathrm{L}}^{\mathrm{w}}=$ Volume of sediment in light liquid paraffin

Gelatinization: To test the gelling property, that is, gelatinization by heating the dispersions in the water bath at $100^{\circ} \mathrm{C}$ for $30 \mathrm{~min}$, a $7 \%$ $\mathrm{w} / \mathrm{v}$ dispersion of starch as well as starch valerate was prepared [4].

Particle size: Using standard sieves, the prepared starch valerate was sieved [4].

Density: The density (g/cc) was calculated using benzene as the solvent by the liquid displacement method [4].

Bulk density: Two graduated cylinders have been taken, starch in one and starch valerate in another have been taken by tapping method to assess bulk density (gm/cc) [4].

Angle of repose: With the assistance of a stand, a funnel was positioned at an acceptable height, starch, as well as starch valerate were passed through the funnel, and markings were drawn, measured, and estimated with scale [4].

Compressibility index: The readings were noted and measured using the following equation by putting the two graduated cylinders containing starch and starch valerate into the bulk density apparatus and allowing taping for 100 times [4].

$(\mathrm{CI})=\mathrm{V}_{0}-\mathrm{V} / \mathrm{V}$

$\mathrm{V}_{0}=$ Original quantity of the powder

V=Ultimate amount of powder

Melting Point: To determine the melting point, some amount of starch valerate was taken into the capillary tube, then put into the melting point apparatus [4].

FTIR: In FTIR, that is, Fourier transforms infrared spectroscopy, the starch valerate spectra were recorded on samples prepared in potassium bromide $(\mathrm{KBr})$ disks by means of a hydrostatic press at a pressure of 6-8 tons. The scan range was between 500 and 4000 $\mathrm{cm}^{-1}$ using a BRUKER FT-IR (Tokyo, Japan) [4].

Ester test: In a test tube, starch valerate $(1 \mathrm{mg})$, ethanol $(1 \mathrm{ml})$, $\mathrm{NaOH}(0.1 \mathrm{ml})$, and phenolphthalein were taken and added as an indicator. A shift in color was observed [4].

of ibuprofen since the tablet is disintegrated within the mouth [5]. Ibuprofen quick-dissolving tablets were prepared by means of direct compression using starch valerate by applying $2^{3}$ factorial design in which 3 independent variables [3 super disintegrants, i.e., starch valerate (a), sodium starch glycolate (b), and crospovidone (c)] and 5 dependent variables [percentage dissolved in 5 min, efficiency of dissolution in $5 \mathrm{~min}$, wetting time, and ratio of water absorption,] were applied. The composition of the various ibuprofen rapid dissolving tablet formulations is shown in Table 1, in which super disintegrants were selected at 2 stages, i.e., higher and lower. At the higher level, that is, $5 \%$ concentration starch valerate (a), sodium starch glycolate (b) and crospovidone (c) and at the lower level, i.e., $0 \%$ concentration of starch valerate (a) sodium starch glycolate (B) and sodium starch glycolate (b) crospovidone (c). Each ingredient was passed through the \# 120 mesh-sized screen before mixing for uniformity in particle size. Starch valerate, sodium starch glycolate, crospovidone, mannitol, and microcrystalline cellulose were precisely measured, combined, and applied to ibuprofen using mortar and pestle. Finally, a powder mixture was applied with talc and magnesium stearate. Mixed blend was eventually compressed using eight-station rotator Press Shakti Machineries Pvt, Ltd., Ahmedabad, India) [6,7].

\section{EVALUATION OF IBUPROFEN FAST-DISSOLVING TABLETS}

\section{Hardness}

In a diametric compression force, the force needed for breaking tablets is tablet hardness. It is usually measured using the Monsanto hardness tester, which allows the force, with the aid of its built-in spring, to fall diametrically on the tablet. It is expressed in terms of $\mathrm{kg} / \mathrm{cm}^{2}$ [7].

\section{Uniformity of weight}

Twenty tablets were taken for the weight variance test to be carried out. Weight variation is known to be the individual variation in tablet weight from the average weight of 20 tablets $[8,9]$.

\section{Friability}

The tablets were initially weighed and then put into the Roche friabilator for friability calculation, where the tablets were allowed to rotate for $4 \mathrm{~min}$ or up to 100 revolutions at $25 \mathrm{rpm}$. After withdrawing from the friabilator, the tablets were reweighted, and the percentage of weight loss was determined using the following formula [6].

$$
\mathrm{F}=\frac{100 * \mathrm{~W}(\text { initial })-\mathrm{W}(\text { Final })}{\mathrm{W}(\text { initial })}
$$

\section{Drug content uniformity}

Ten tablets were weighed and powdered to determine the uniformity of the drug content. A powder equal to $10 \mathrm{mg}$ of the drug, i.e., ibuprofen was extracted and filtered into a 7.4 phosphate buffer, whereby the content of ibuprofen was determined by spectrophotometric measurement of the absorbance at $274 \mathrm{~nm}$ after sufficient dilution with a 7.4 phosphate buffer and was measured as an average of three determinations [9].

\section{Wetting time}

The wetting time can be calculated by taking a petri dish of about 10 $\mathrm{cm}$ in diameter and five tissue papers and an amaranth solution (watersoluble dye-for-color). In the petri dish, the tissue paper was put in and about $10 \mathrm{ml}$ of amaranth solution was poured into it so that the tissue paper would absorb the color solution. The tablets were then placed individually on the surface of the tissue paper, surface and the time taken by the tablet to absorb the color was noted [7].

\section{Water absorption ratio}

The same wetting time method was followed to find out the water absorption ratio, but the tablet should be re-weighted after the tablet absorbs the color water and should be measured using the following formula [7].

$$
\mathrm{R}=\frac{100\left(\mathrm{~W}_{\mathrm{a}}-\mathrm{W}_{\mathrm{b}}\right)}{\mathrm{W}_{\mathrm{b}}}
$$

Where,

$\mathrm{W}_{\mathrm{a}}$ - weight of tablet after water absorption

$\mathrm{W}_{\mathrm{b}}$ - weight of tablet before water absorption

\section{In-vitro disintegration time}

The prepared tablets were placed into the disintegration testing apparatus (LABINDIA) containing $900 \mathrm{ml}$ of the 7.2 phosphate as the 
Table 1: Formulae of Ibuprofen fast-dissolving tablets employing starch valerate

\begin{tabular}{|c|c|c|c|c|c|c|c|c|c|}
\hline Ingredients (mg per tablet) & F1 & F2 & F3 & F4 & F5 & F6 & F7 & F8 & F9 \\
\hline Ibuprofen & 100 & 100 & 100 & 100 & 100 & 100 & 100 & 100 & 100 \\
\hline Starch xanthate & 25 & 50 & 100 & 100 & 25 & 50 & 25 & 50 & -- \\
\hline Sodium starch glycolate & -- & -- & 25 & 25 & -- & -- & 25 & 25 & -- \\
\hline Croscarmellose sodium & -- & -- & -- & -- & 25 & 25 & 25 & 25 & -- \\
\hline Mannitol & 155 & 130 & 130 & 105 & 130 & 105 & 105 & 80 & 180 \\
\hline Micro crystalline cellulose & 200 & 200 & 200 & 200 & 200 & 200 & 200 & 200 & 200 \\
\hline Talc & 10 & 10 & 10 & 10 & 10 & 10 & 10 & 10 & 10 \\
\hline Total & 500 & 500 & 500 & 500 & 500 & 500 & 500 & 500 & 500 \\
\hline
\end{tabular}

disintegration media, maintained at a temperature range of $37 \pm 0.2^{\circ} \mathrm{C}$. The time taken by the tablet for complete disintegration with no solid, palatable mass in the apparatus was recorded [7].

\section{In-vitro disintegration rate studies}

An 8 - stage dissolution apparatus (Electro-Lab, TDT-08L) was used to study the dissolution of ibuprofen fast-dissolving tablets. Before dropping the tablets into the apparatus for testing, the buffer $(7.2 \mathrm{pH}-$ phosphate buffer) of $900 \mathrm{ml}$ was poured into each basket and it should reach with the temperature required, i.e., $37 \pm 0.5^{\circ} \mathrm{C}$, paddles should be fitted and rpm was set to $50 \mathrm{rpm}$. Once the apparatus is all set to use, the tablets were dropped, at pre-determined time intervals, the samples of $5 \mathrm{ml}$ were collected, filtered, diluted if required, and assayed at 224 nm using Shimadzu UV-1800 UV/Visible Scanning Spectrophotometer. Cumulative percentage release was calculated using standard absorbance from the calibration curve. All the dissolution experiments were conducted in triplicate $(n=3)$ [7].

\section{Optimization technique}

Selecting the best elements from the set of available alternatives is optimization. Optimization is an experimental design which is a statistical design that prescribes a set of combinations of variables. The number and layout of these design points within the experimental region depend upon the number of effects that must be determined. Depending on the number of factors, their levels, possible interactions, and order of the model, various experimental designs are selected. It is a process of finding the best way of using the existing resources while taking into account of all factors that influences the research, thereby providing experimental and manufactural steps to give away the formulation quantitatively into a product.

Factorial designs (FDs) are very often used response surface designs. A factorial experiment is one in which all the levels of a given factor are combined with all levels of every other factor in the experiment. These are generally based upon first-degree mathematical models. Hence, by applying this in the present work, by controlling the variables and changing at time until adequate results obtained, also deals with an attempt of systematic formulation for optimizing ibuprofen fastdissolving tablets employing starch valerate which is a novel super disintegrant, sodium starch glycolate, and crospovidone as super disintegrants. In the $2^{3}$ factorial design, these super disintegrants were applied to investigate the interaction effects of three variables, i.e., starch valerate, sodium starch glycolate, and crospovidone [7]. In each case, to find the formula with less disintegration time and more dissolution efficiency in $5 \mathrm{~min}$ and to permit random choice of selection of tablets with immediate release of drug within 5 min.

\section{Comparison of optimized formulation with marketed formulation} The optimized formulation was compared with the marketed formulation (IBUPROFEN XPEN FLASHTAB) containing $100 \mathrm{mg}$ of ibuprofen.

\section{Label claim of marketed formulation}

Each IBUPROFEN XFEN FLASHTAB film-coated tablet of $100 \mathrm{mg}$ contains; titanium dioxide to protect from light, moisture, and temperature as color of tablets. It is manufactured by ATHENA
Pharmaceuticals Pvt. Ltd., Chemical zone, Ambernath west, INDIA - 421501 with manufactured license no. J/176/2019, batch no 5340K028, manufactured date $11 / 2019$, and expiry date $10 / 2020$.

\section{RESULTS AND DISCUSSION}

The prepared starch valerate was found to be fine, amorphous, and free-flowing powder. It is insoluble in water, aqueous buffers $\left(\mathrm{p}^{\mathrm{H}} 1,2\right.$, $3,4,5,6$, and 7 ) and also in organic solvents (methanol, petroleum ether, dichloromethane, and chloroform) which were tested with $1 \% \mathrm{w} / \mathrm{v}$ of starch valerate dispersion. Starch valerate physical and micromeritic properties were analyzed, indicated good flow and compressibility properties which are needed for a solid dosage form to manufacture, and results were summarized in Table 2 . Starch valerate has exhibited good swelling property in water when compared to swelling in light liquid paraffin. The swelling index was $125.2 \%$. The density of starch valerate was found to be 0.9908 gm/cc. The FTIR spectra of starch and starch valerate were shown in Figs. 1 and 2. The presence of peaks absorption at $1639.97 \mathrm{~cm}^{-1}$, which is a characteristic peak of ester, so from FTIR studies, it was concluded that starch valerate (ester) was formed when starch was allowed to react with valeric acid. The test for ester was performed and disappearance of pink color confirmed the presence of ester, i.e., starch valerate. When starch valerate was taken into capillary tube, for testing its melting point using melting point apparatus, it was found to melt at $182.6^{\circ} \mathrm{C}$.

\section{VALUATION OF TABLETS}

The fast-dissolving tablets each containing $100 \mathrm{mg}$ of ibuprofen could be prepared by employing starch valerate and other known super disintegrants such as sodium starch glycolate and crospovidone by direct compression tablet punching method.

\section{Hardness}

The tablet hardness of the optimized formulation as well as marketed were in the range of $3.5-4 \mathrm{~kg} / \mathrm{cm}^{2}$, indicates good strength with a capability to resist its physical and pre-functionary stress conditions during traveling and handling. The hardness of the tablet is greater when compared to tablets, i.e., $(2.4 \pm 0.04$ to $3.4 \pm 0.13)$ which were prepared by Durga Bhavani P [1].

\section{Friability}

By performing friability test to all the optimized formulations as well as marketed formulation, the weight loss was found to be $<0.15 \%$ indicating good mechanical resistance of tablets. Thus, it was proved that tablets could withstand the pressure, mechanical shocks during handling, transportation, storage, and manufacturing processes. The friability of the tablet is more when compared to the tablets, i.e., $(0.652$ to 0.986 ) which were prepared by Ranjit Prasad Swain [8].

\section{Drug content}

The prepared fast-dissolving tablets containing ibuprofen claimed within $200 \pm 5 \%$ of that of the label which is higher in comparison to the tablets, i.e., $(96.54 \pm 0.16$ to $101 \pm 0.01)$ which were prepared by Ranjit Prasad Swain [8]. 
Wetting time and water absorption ratio of tablets

Wetting time and water absorption ratio of tablets formulated as well as marketed resulted to be within the limits that are prescribed and obeyed the criteria of fast-dissolving tablets. The wetting time at initial and final times was depicted in Fig. 3. The optimized formulation F-8, which consists of $5 \%$ of starch valerate, sodium starch glycolate, and crospovidone has shown less wetting time when compared to the wetting of tablets, i.e., $(9 \pm 0.69$ to $210 \pm 0.63)$ which were prepared by Ranjit Prasad Swain [8] and water absorption ratio was relatively more

Table 2: Physical and micromeritic properties of prepared novel super disintegrant-starch valerate

\begin{tabular}{ll}
\hline Parameters & Observation \\
\hline Solubility & $\begin{array}{l}\text { Insoluble in all aqueous and organic } \\
\text { solvents. }\end{array}$ \\
$\mathrm{pH}$ & $3.48 \pm 0.02$ \\
Viscosity & $1.0680 .008 \mathrm{cps}$ \\
Swelling index & $125.2 \%$ \\
Gelling property & Np gelation of starch valerate particles, \\
& whereas starch particles formed gel \\
Particle size & $5.82 \pm 2.124 \mu \mathrm{m}$ \\
Density & $0.9908 \pm 0.0004 \mathrm{~g} / \mathrm{cc}$ \\
Bulk density & $0.52 \pm 0.03 \mathrm{~g} / \mathrm{cc}$ \\
Angle of repose & $13.39^{\circ}$ (good) \\
Compressibility index (CI) & $25 \pm 0.01$ \\
Melting point & $182.6^{\circ}$ \\
\hline
\end{tabular}

when compared to the tablets, i.e., (0.743-2.83) which were prepared by Ranjit Prasad Swain [8] (Tables 3-5).

\section{In-vitro disintegration time}

As mentioned in Table 5, the disintegration time of all formulated tablets and marketed formulation was laid between $12 \pm 0.02$ and $30.0 \pm 0.02 \mathrm{~s}$ which is comparatively more to the tablets, i.e., (38-80 $\mathrm{min}$ ) which were prepared by Ranjit Prasad Swain [8].

\section{In-vitro dissolution studies}

From in-vitro dissolution studies of fast-dissolving tablets containing ibuprofen employing starch valerate, their profile was shown in Fig. 4a and $b$ and the optimized formulation with marketed formulation dissolution profile was compared as given in Tables 4 and 5 . The dissolution parameters of all the formulations, i.e., F-1 to F-8 and marketed formulations, were given in Table 4, whereas the optimized formulation, i.e., $\mathrm{F}-8$ has shown more $\mathrm{PD}_{5}$ (percent dissolved in $5 \mathrm{~min}$ ) which contains $5 \%$ starch valerate, sodium starch glycolate, and crospovidone. Even $\mathrm{DE}_{5 \%}$ (dissolution efficiency in $5 \mathrm{~min}$ ) has shown more in the optimized formulation, F-8 which is more when compared to the tablets, i.e., ( $42 \pm 0.45$ to $149 \pm 0.26$ ) prepared by Ranjit Prasad Swain [8]. The $\mathrm{PD}_{5}$ and $\mathrm{DE}_{5 \%}$ reveal that starch valerate was effective at $5 \%$ starch valerate, $5 \%$ sodium starch glycolate, and $5 \%$ crospovidone when the formulations were made by direct compression using these super disintegrants. The number of folds in $\mathrm{DE}_{5 \%}$ was given in Table 4. Therefore, from the results, it was concluded that starch valerate (novel super disintegrant) could be used as super disintegrant in the formulation of fast-dissolving tablets of ibuprofen.

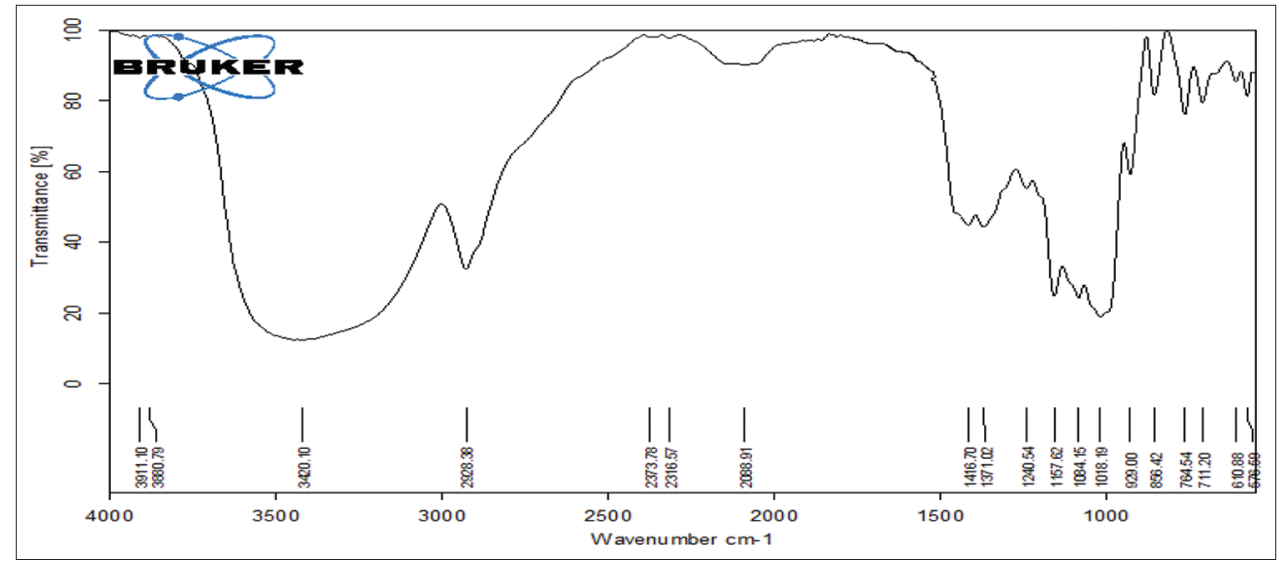

Fig. 1: FTIR spectra of potato starch

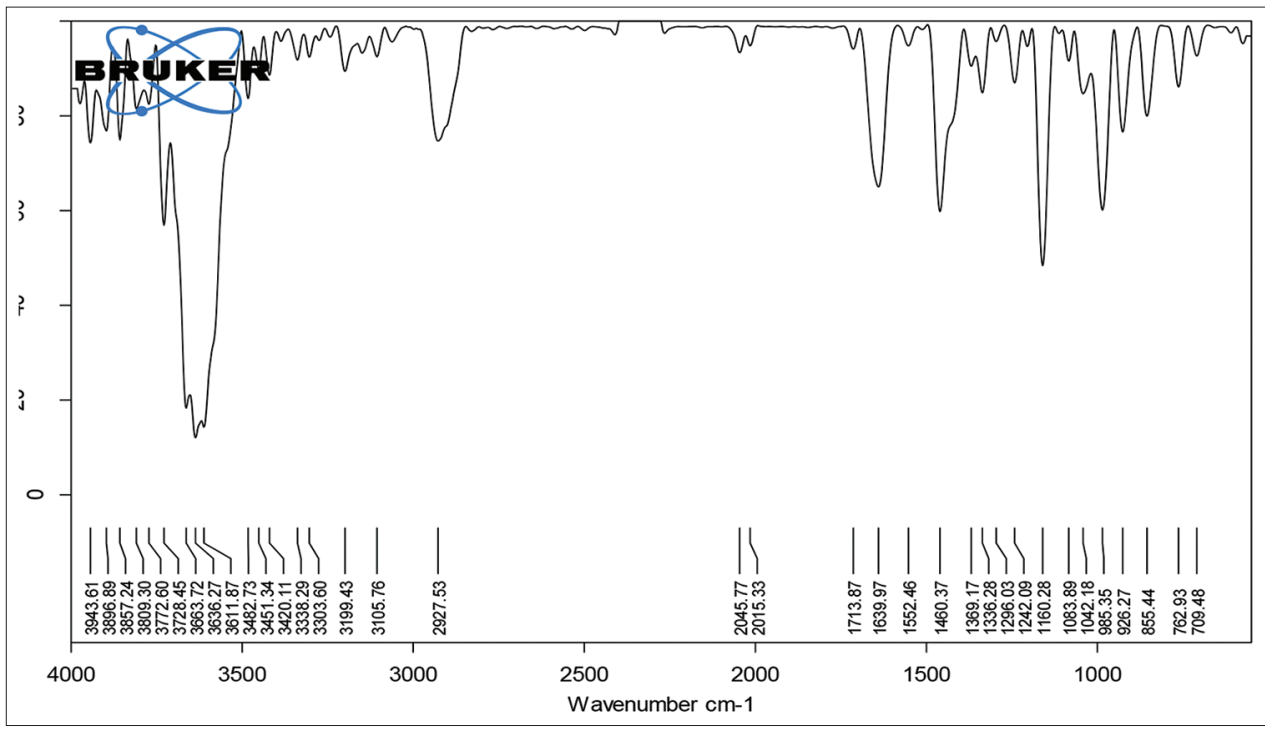

Fig. 2: FTIR spectra of starch valerate 


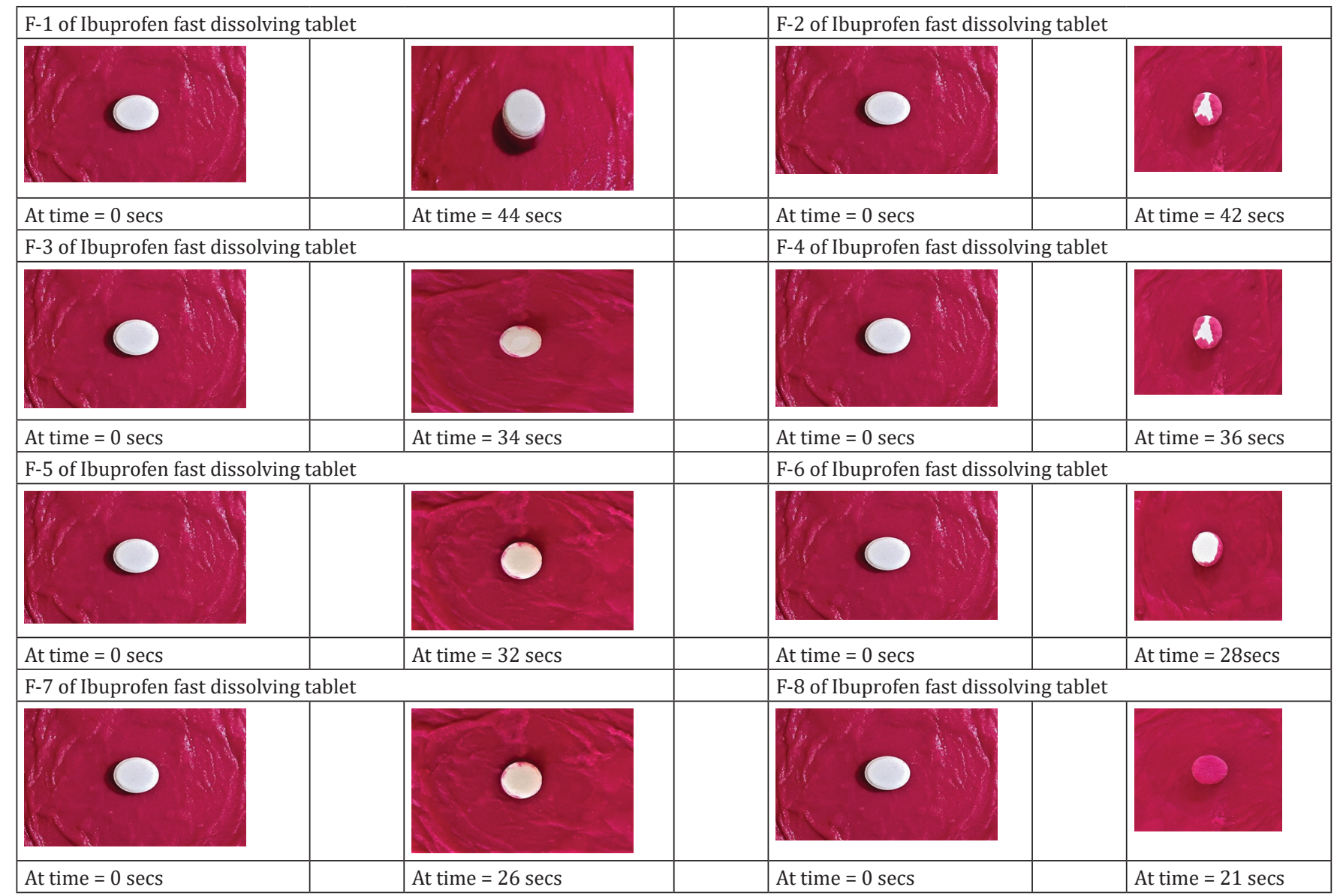

Fig. 3: Ibuprofen fast dissolving tablets prepared employing starch valerate

Table 3: Comparison of physical properties: Hardness, friability, drug content, disintegration time, wetting time, and water absorption ratio of ibuprofen fast-dissolving tablets employing starch itaconate with marketed formulation

\begin{tabular}{|c|c|c|c|c|c|c|}
\hline Formulation & $\begin{array}{l}\text { Hardness } \\
\left(\mathrm{kg} / \mathrm{cm}^{2}\right) \mathrm{n} \pm \text { S.D }\end{array}$ & $\begin{array}{l}\text { Friability } \\
(\%) n \pm \text { S.D }\end{array}$ & $\begin{array}{l}\text { Drug content } \\
\mathrm{mg} / \mathrm{tab}) \mathrm{n} \pm \text { S.D }\end{array}$ & $\begin{array}{l}\text { Disintegration } \\
\text { time (s) } n \pm S . D\end{array}$ & $\begin{array}{l}\text { Wetting time } \\
\text { (sec) } n \pm \text { S.D }\end{array}$ & $\begin{array}{l}\text { Water absorption } \\
\text { ratio (\%) } n \pm \text { S.D }\end{array}$ \\
\hline F1 & $3.8 \pm 0.01$ & $0.12 \pm 0.013$ & $97.13 \pm 0.71$ & $30 \pm 0.02$ & $44 \pm 0.10$ & $30.61 \pm 0.12$ \\
\hline F2 & $3.7 \pm 0.03$ & $0.11 \pm 0.015$ & $98.01 \pm 0.79$ & $27 \pm 0.03$ & $42 \pm 0.08$ & $61.22 \pm 0.18$ \\
\hline F3 & $3.7 \pm 0.01$ & $0.11 \pm 0.012$ & $98.27 \pm 0.63$ & $25 \pm 0.02$ & $34 \pm 0.03$ & $79.59 \pm 0.16$ \\
\hline F4 & $3.6 \pm 0.04$ & $0.12 \pm 0.014$ & $98.72 \pm 0.55$ & $25 \pm 0.02$ & $36 \pm 0.12$ & $86.01 \pm 0.15$ \\
\hline F5 & $3.7 \pm 0.03$ & $0.12 \pm 0.012$ & $99.43 \pm 0.56$ & $15 \pm 0.01$ & $32 \pm 0.32$ & $89.20 \pm 0.21$ \\
\hline F6 & $3.8 \pm 0.01$ & $0.11 \pm 0.012$ & $99.55 \pm 0.18$ & $18 \pm 0.02$ & $28 \pm 0.11$ & $91.03 \pm 0.12$ \\
\hline F7 & $3.7 \pm 0.02$ & $0.12 \pm 0.014$ & $99.66 \pm 0.57$ & $14 \pm 0.01$ & $26 \pm 0.13$ & $99.89 \pm 0.15$ \\
\hline F8 & $3.7 \pm 0.04$ & $0.12 \pm 0.013$ & $99.89 \pm 0.11$ & $12 \pm 0.02$ & $21 \pm 0.09$ & $100 \pm 0.09$ \\
\hline Marketed formulation & $3.8 \pm 0.01$ & $0.11 \pm 0.012$ & $99.12 \pm 0.11$ & $18 \pm 0.04$ & $27 \pm 0.14$ & $79 \pm 0.21$ \\
\hline
\end{tabular}

*SD Standard deviation from mean, $\mathrm{n}=3$

Table 4: Comparison of dissolution parameters of ibuprofen fast-dissolving tablets formulated employing starch valerate and other known super disintegrants with marketed formulation

\begin{tabular}{llllllllll}
\hline Time (min) & F-1 & F-2 & F-3 & F-4 & F-5 & F-6 & F-7 & F-8 & $\begin{array}{l}\text { Marketed } \\
\text { formulation }\end{array}$ \\
\hline $\mathrm{PD}_{5}$ & $2.89 \pm 0.12$ & $25.91 \pm 013$ & $62.80 \pm 0.17$ & $64.68 \pm 0.18$ & $66.79 \pm 0.15$ & $68.75 \pm 0.12$ & $69.28 \pm 0.14$ & $90.34 \pm 0.11$ & $78.20 \pm 0.13$ \\
$\mathrm{DE}_{5 \%}$ & $2.6 \pm 0.11$ & $27.2 \pm 0.09$ & $52.80 \pm 0.05$ & $60.8 \pm 0.12$ & $66.4 \pm 0.14$ & $67.8 \pm 0.08$ & $72.1 \pm 0.13$ & $91.30 \pm 0.01$ & $30.32 \pm 0.12$ \\
No of folds & - & 10.46 & 20.30 & 23.38 & 25.53 & 26.07 & 26.38 & 35.11 & -- \\
increase in $\mathrm{DE}_{5} \%$ & & & & & & & & & \\
\hline
\end{tabular}

$\mathrm{PD}_{5}:$ Percent dissolved in $5 \mathrm{~min}, \mathrm{DE}_{5 \%}$ : Dissolution efficiency in $5 \mathrm{~min},{ }^{*} \mathrm{SD}$ : Standard deviation from mean, $\mathrm{n}=3$ 


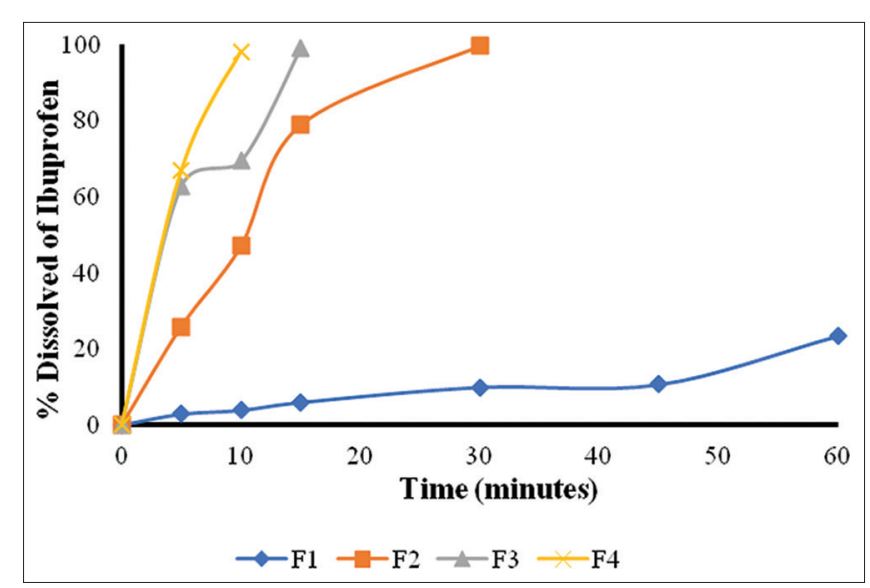

Fig. 4a: Dissolution profiles of Ibuprofen fast dissolving tablets prepared employing starch valerate [F1-F4]

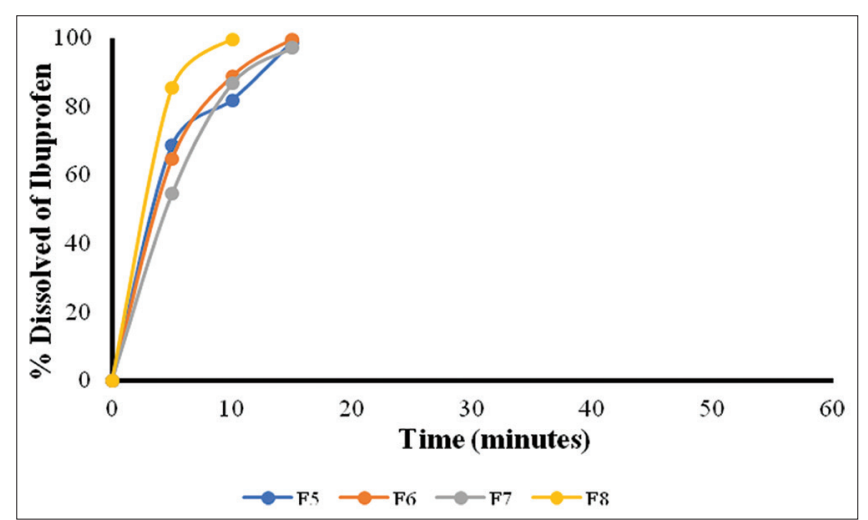

Fig. 4b: Dissolution profiles of Ibuprofen fast dissolving tablets prepared employing starch valerate (F5-F8)
The disintegration time and dissolution efficiency in 10 min indicate that the dependent variables strongly depend on the independent variables. The fitted equations relating the disintegration time and dissolution efficiency by the end of $5 \mathrm{~min}$ to the transform factors are shown in the following equations,

Disintegration time $=+45.88+3.38 \mathrm{~A}-5.63 \mathrm{~B}-5.13 \mathrm{C}+0.63 \mathrm{AB}-0.37 \mathrm{AC}$ $-2.12 \mathrm{BC}+1.12 \mathrm{ABC} .(\mathrm{R} 2=1.000)$

Dissolution efficiency in $5 \mathrm{~min}=+28.76+11.96 \mathrm{~A}+10.26 \mathrm{~B}+16.34+$ $9.01 \mathrm{AB}+6.64 \mathrm{AC}+4.39 \mathrm{BC}+8.04 .(\mathrm{R} 2=1.000)$

The value of the $\mathrm{R}^{2}$ indicates a good fit. The polynomial equations can be used to draw a conclusion after considering the magnitude of the coefficient and the mathematical sign it carries (positive or negative). Once the polynomial equation, which relates the levels of each factor and their corresponding interactions with disintegration time and percent release in $5 \mathrm{~min}$, the surface response curves and contour plots were constructed using software.

The response surface plots and contour plots reveal that, with the increase in concentration of starch valerate (A), sodium starch glycolate (B), and crospovidone (C), the disintegration time decreases. The effects of $A$ and $B$ on disintegration time are shown in Figs. 5.1-5.3. The contour plots were found to be linear up to certain extent, thereafter they were non-linear. From the contour plot in Fig. 5.3, it was determined that a less disintegration time can be obtained with A-level range between 3.75 and $5 \%$ and $B$ level range from 3.75 to $5 \%$. The effects of B and C are shown in Fig. 5.4, where the contour plots were found to be linear, indicating linear relationship between B and C. From the contour plots, the linearity was found, indicating the linear relationship between $B$ and C. Furthermore, it was determined from the contour plot (Fig. 5.4) that the less disintegration time was obtained with B-level in between 3.75 and $5 \%$ and C-level range from 3.75 to $5 \%$ The effects of $\mathrm{A}$ and $\mathrm{C}$ were depicted in Fig. 5.5, the contour plots were almost found to be linear indicating a linear relationship between A and C. From the contour plot, it was determined that less disintegration time was

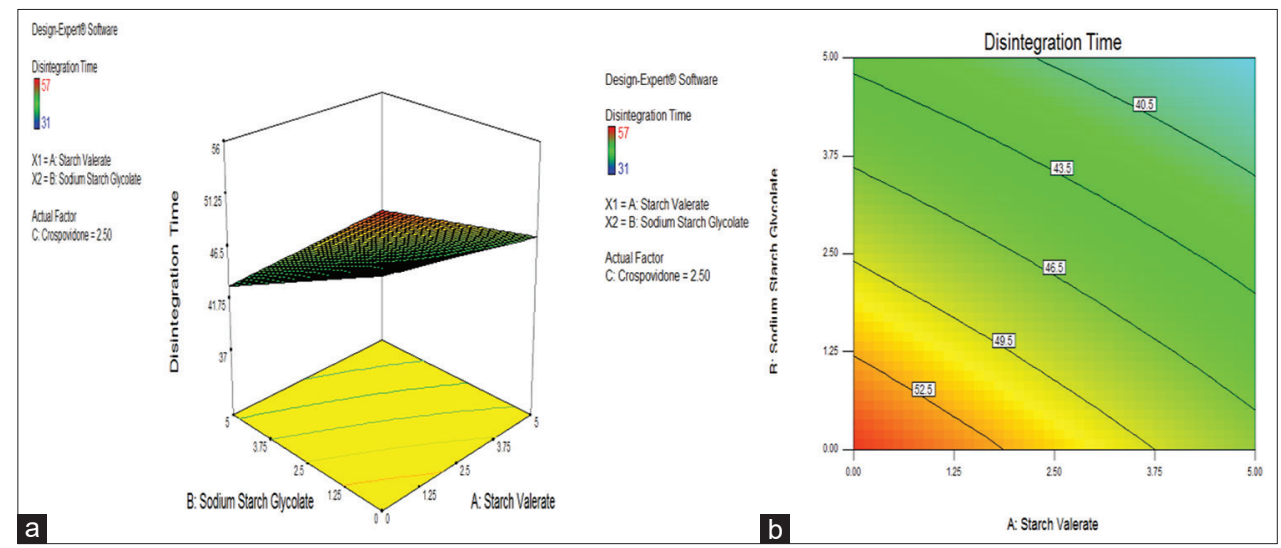

Fig. 5.1: a) Surface plot, b) Contour plot of Ibuprofen fast dissolving tablets (Effect of Starch Valerate and Sodium starch glycolate on disintegration time)

Table 5: Comparison of ibuprofen percent dissolved from dissolving tablets employing starch valerate with marketed formulation

\begin{tabular}{|c|c|c|c|c|c|c|c|c|c|}
\hline Time (min) & F1 & F2 & F3 & F4 & F5 & F6 & F7 & F8 & $\begin{array}{l}\text { Marketed } \\
\text { formulation }\end{array}$ \\
\hline 5 & $02.89 \pm 0.12$ & $25.91 \pm 0.13$ & $62.80 \pm 0.17$ & $66.79 \pm 0.18$ & $68.75 \pm 0.15$ & $64.68 \pm 0.12$ & $54.57 \pm 0.14$ & $92.34 \pm 0.11$ & $62.20 \pm 0.11$ \\
\hline 10 & $03.92 \pm 0.11$ & $47.07 \pm 0.12$ & $69.39 \pm 0.10$ & $98.17 \pm 0.15$ & $81.97 \pm 0.10$ & $88.82 \pm 0.11$ & $86.87 \pm 0.12$ & $99.76 \pm 0.09$ & $78.21 \pm 0.19$ \\
\hline 15 & $06.00 \pm 0.10$ & $78.95 \pm 0.11$ & $99.21 \pm 0.02$ & --- & $99.05 \pm 0.08$ & $99.61 \pm 0.02$ & $97.18 \pm 0.10$ & --- & $93.52 \pm 0.12$ \\
\hline 30 & $09.97 \pm 0.20$ & $99.67 \pm 0.08$ & --- & --- & --- & --- & --- & --- & --- \\
\hline 45 & $10.69 \pm 0.18$ & --- & --- & --- & --- & --- & --- & --- & --- \\
\hline 60 & $23.43 \pm 0.12$ & --- & --- & --- & --- & --- & --- & --- & --- \\
\hline
\end{tabular}

*SD: Standard deviation from mean, $\mathrm{n}=3$ 


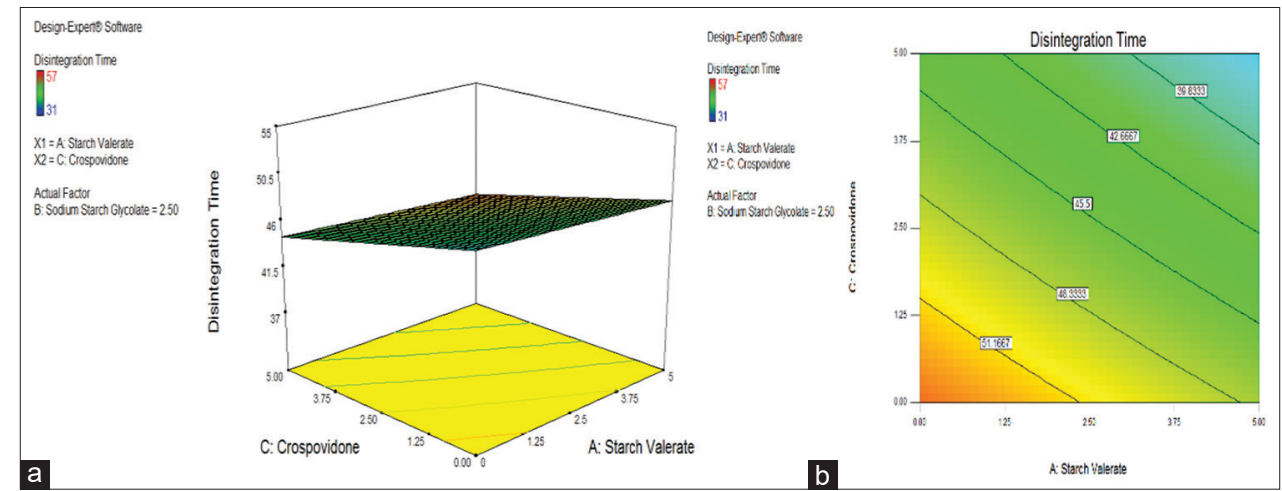

Fig. 5.2: a) Surface plot, b) Contour plot of Ibuprofen fast dissolving tablets (Effect of Starch Valerate and Crospovidone on disintegration time)

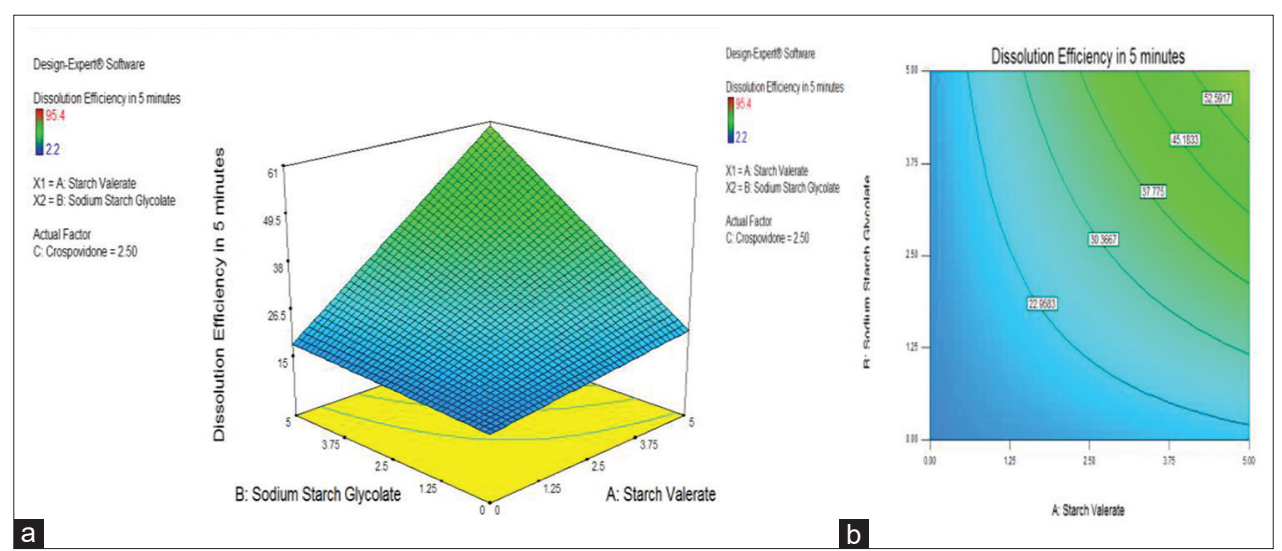

Fig. 5.3: a) Surface plot, b) Contour plot of Ibuprofen fast dissolving tablets (Effect of Sodium starch glycolate and Crospovidone on disintegration time)

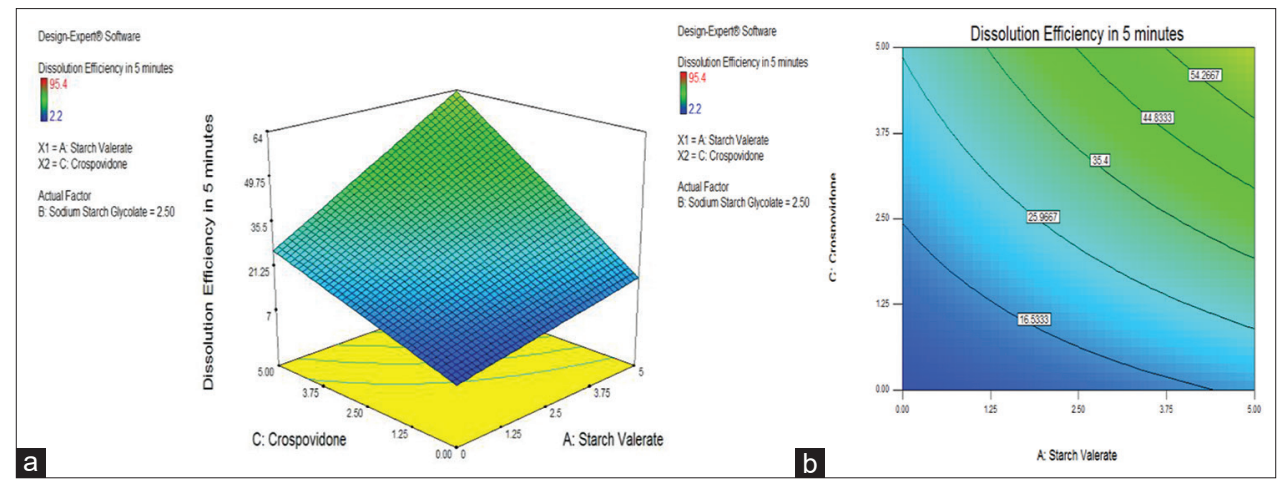

Fig. 5.4: a) Surface plot, b) Contour plot of Ibuprofen fast dissolving tablets (Effect of Sodium starch glycolate and Crospovidone on dissolution efficiency in $5 \mathrm{~min}$ )

obtained with A-level in between 3.75 and 5\% and C-level between 3.75 and $5 \%$. From this, we can conclude that less disintegration time can be achieved when the factor-A was used in the concentration range from 3.75 to $5 \%$ B and C-levels in the range of 3.75 to $5 \%$ of the total weight of the tablet.

The response surface plots and contour plots reveal that, with the increase in concentration of starch valerate (A), sodium starch glycolate (B), and crospovidone (C), the dissolution efficiency in 5 min increases. The effect of A and B on dissolution efficiency in $5 \mathrm{~min}$ is shown in Fig. 5.6, the contour plots were found to linear to the maximum extent. From the contour plot, it was determined that more dissolution efficiency can be obtained with A-level range at 3.75 to $5 \%$ and B-level range 3.75-5\%. The effects of B and C are depicted in Fig. 5.7, where the contour plots were found to be linear, indicating the linear relationship between B and C. From the contour plot, it was determined that more dissolution efficiency can be obtained with B-level range between 3.75 and 5\%. The effects of $A$ and $C$ are shown in Fig. 5.8, where the contour plots were found to be linear, indicating the linear relationship between A and C. From the contour plot, it was determined that more dissolution efficiency in $5 \mathrm{~min}$ can be obtained in A-level range between 3.75 and $5 \%$ and C-level in a range between 3.75 and $5 \%$. 


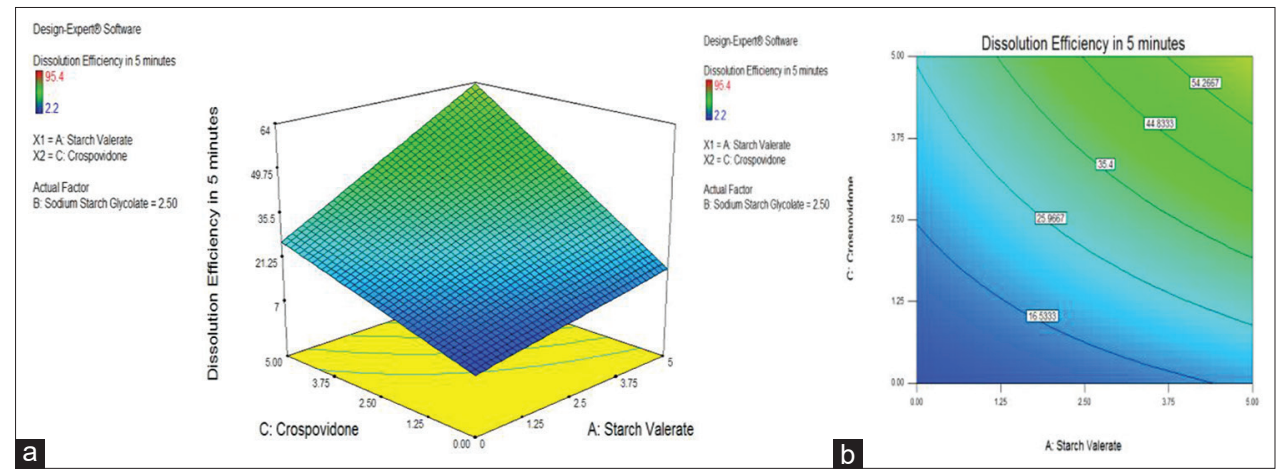

Fig. 5.5: a) Surface plot, B) Contour plot of Ibuprofen fast dissolving tablets (Effect of Starch Valerate and Crospovidone on dissolution efficiency in $5 \mathrm{~min}$ )

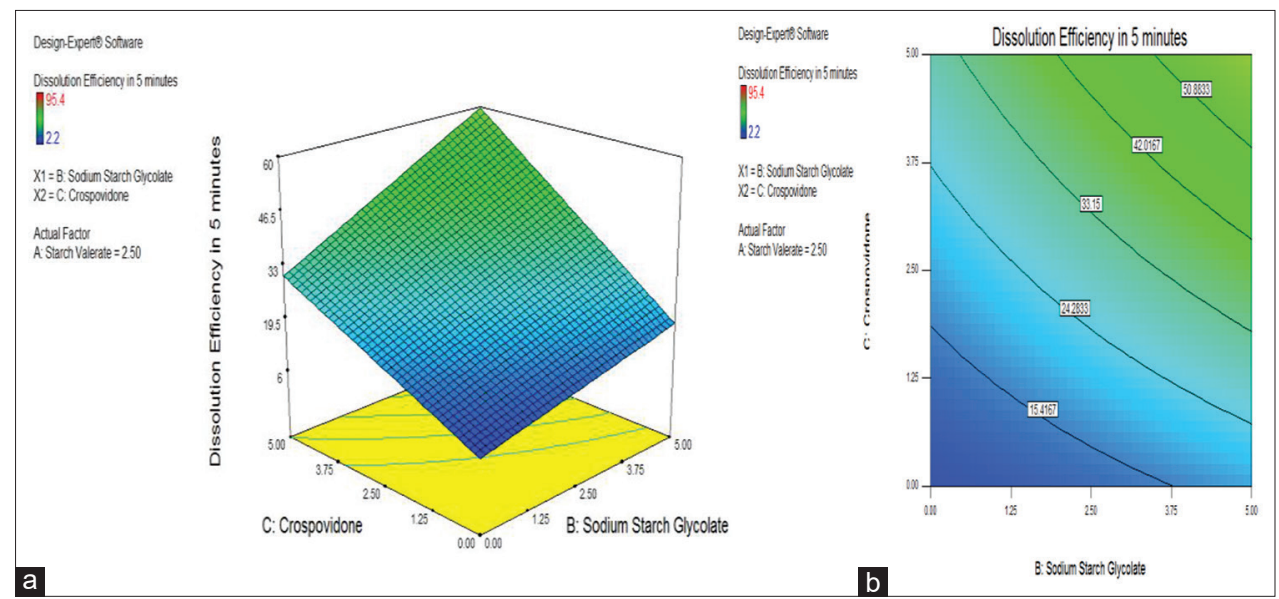

Fig. 5.6: a) Surface plot, b) Contour plot of Ibuprofen fast dissolving tablets (Effect of Sodium starch glycolate and Crospovidone on dissolution efficiency in $5 \mathrm{~min}$ )

\section{CONCLUSION}

Starch valerate is an efficient, super disintegrant for fast-dissolving tablets. The disintegration and dissolution efficiency of the fastdissolving tablets of ibuprofen was good and depended on the concentration of super disintegrant employed, i.e., starch valerate, sodium starch glycolate, and crospovidone. Overall, starch valerate was found to be a super-disintegrant which enhanced the dissolution efficiency when combined with sodium starch glycolate and crospovidone with the ibuprofen.

\section{AUTHORS' CONTRIBUTIONS}

Experimental design, guidance, supervision, review work, experimental work, development and optimization of the formulations, interpretation of result, and writing of this manuscript were done by both $\mathrm{Dr}$. R. Santosh Kumar and Ms. Ramya. Both authors read and approve the final manuscript.

\section{CONFLICTS OF INTEREST}

The authors confirm that the article content has no conflicts of interest.

\section{AUTHORS' FUNDING}

The work was funded by GITAM Institute of Pharmacy, GITAM (Deemed to be University).

\section{REFERENCES}

1. Bhavani PD, Rao NG. Formulation and evaluation of valsartan fast disintegrating tablets by vacuum drying technique. Asian J Pharm Clin Res 2016;9:73-9.

2. Kumar S, Garg SK. Fast dissolving tablets (FDTs): Current status, new market opportunities, recent advances in manufacturing technologies and future prospects. Int J Pharm Pharm Sci 2014;6:22-35.

3. Kumar S, Mudili S. Formulation and evaluation of statistically designed ibuprofen fastdissolving tablets employing starch glutamate as a novel superdisintegrant. Asian J Pharm Clin Res 2019;12:85-94.

4. Kumar RS, Yagnesh TN, Kumar VG. Optimisation of ibuprofen fast dissolving tablets employing starch xanthate using 23 factorial design. Int J Appl Pharm 2017;9:51-9.

5. Tayebi H, Mortazavi SA. Formulation and evaluation of a novel matrix-type orally disintegrating ibuprofen tablet. Iran J Pharm Res 2011;10:469-79.

6. Kumar RS, Yagnesh TN. Synthesis, characterization and evaluation of starch xanthate as a superdisintegrant in the formulation of fast dissolving tablets. Int J Appl Pharm 2018;10:249-58.

7. Kumar RS, Annu K, Latha BK, Mallika T. Design, optimization and evaluation of ibuprofen fast dissolving tablets employing starch phthalate-a novel superdisintegrant. Int J Curr Pharm Res 2019;11:47-53.

8. Swain RP, Satish P, Subudhi BB, Panda S. Formulation and optimization of orodispersible tablets of ibuprofen. Int J Pharm Pharm Sci 2015;7:441-7.

9. Purkayastha HD, Nath B. Formulation and evaluation of oral fast disintegrating tablet of ibuprofen using two super disintegrants. Int J Curr Pharm Res 2017;9:92-5. 